\title{
Recent Reforms in Spanish Housing Markets: An Evaluation using a DSGE Model*
}

\author{
Juan S. Mora-Sanguinetti ${ }^{\dagger}$ \\ Banco de España-Eurosystem
}

\author{
Margarita Rubio ${ }^{\ddagger}$ \\ University of Nottingham
}

March 25, 2014

\begin{abstract}
After a long academic debate, Spain finally repealed in 2012 the deduction for home purchase. The abrogation took effect in 2013. In parallel, the VAT for the purchase of new housing was increased after a short period in which it had a reduced rate. The aim of this paper is to assess the macroeconomic effects of these two relevant housing market reforms. In order to do that, we use a dynamic stochastic general equilibrium (DSGE) model calibrated to capture the key ratios of the Spanish economy. The model includes a housing market, covering both the rental market side and the property market side and credit-constrained agents. We find that these measures drive down housing prices and have a negative impact on output and employment in the construction sector. However, in the long run, this last effect is offset by the benefits of a reduction in distortionary taxes.
\end{abstract}

Keywords: Housing Market Reforms, Rental Market, House Prices, Home Purchase Deduction, VAT on New Home Purchase

JEL Codes: E51, E6, R31, K34

\footnotetext{
${ }^{*}$ We are highly indebted to Carlos Thomas, who reviewed the manuscript in depth and provided useful suggestions. We thank Eva Ortega, Maica Sánchez Carretero, Miguel Ángel López-García and Laura Vázquez de Diego for valuable comments. We are also grateful to seminar participants at the XVI Applied Economics Meeting (Granada, 2013) and the XXI Encuentro de Economía Pública (Girona, 2014). The views expressed in this article are those of the authors and should not be attributed to the Banco de España or the Eurosystem. The usual disclaimer applies.

${ }^{\dagger}$ Alcala 48, 28014, Madrid, Spain. E-mail: juans.mora@bde.es

${ }^{\ddagger}$ Sir Clive Granger Building, University Park, Nottingham, NG7 2RD, UK. E-mail: margarita.rubio@nottingham.ac.uk
} 


\section{Introduction}

The housing market has been the main driver of the Spanish economy over the long expansionary cycle that ended in 2007. More specifically, the construction sector had a very high weight over the total hours worked in Spain (13\%) in the period 1996-2007. The weight of the sector was much lower in other EU economies $(8 \%)$ or the US $(7 \%)$. The same can be said about value added. The construction sector produced $9.9 \%$ of the total value added of the Spanish economy while it amounted to $6.3 \%$ in the EU or $4.7 \%$ in the US over the same period. The sector, despite the crisis, is still very important in the Spanish economy, involving in the most recent years (2008-2010) 11\% of the hours worked and $13 \%$ of total value added. The housing market in Spain is also suffering from structural problems, such as the pronounced imbalance between home ownership versus rental compared to other European or OECD countries (see Figure 1 in the Appendix and, among others, Andrews et al. 2011 or Mora-Sanguinetti, 2012) or the concentration of resources and investment in the construction sector (which would not be disconnected from the above, Arce and López-Salido, 2011). The housing market adjustment and its consequences have focused the attention of institutions such as the OECD (2010) or the European Commission (2012), who have called to bridge the gap between tenancy and home ownership and to mitigate its weight in economic activity. Consequently, accurately evaluating the economic impacts of housing policies is essential for understanding the overall macroeconomic performance of the Spanish economy.

Between 2011 and 2012 the Spanish government passed several reform packages focused on the housing market, affecting both its taxation and its general regulation. Chronologically we can highlight the following reforms. First, in August 2011 the Government approved the implementation of a superreduced VAT for home purchase (up to December 2011). This new VAT was subsequently extended until December 2012. In December 2011, the government reintroduced the deduction for home purchase for all income levels for operations taking place in 2012 and retroactively to those which took place in 2011. In other words, through its reinstitution in 2011, the deduction for home purchase was in force since its adoption in $1978^{1}$ (with the exception of a brief period of derogation for high-income taxpayers who were compensated in 2011). In May 2012 the Council of Ministers presented a package of measures that included a proposal to reform the Urban Tenancies Act (Ley de Arrendamientos Urbanos), some specific

\footnotetext{
${ }^{1}$ The deduction was first introduced in the first Law of Income Tax on Individuals (IRPF) in 1978. Law 44/1978 of 8 september 1978. This statement is necessarily simplistic since it ignores the changes that have affected the taxation of housing in that long period (for example, see the discussion provided by Onrubia Fernández et al. 2004).
} 
procedural measures to speed up the eviction procedures for non-paying (or not-complying) tenants and some fiscal measures related to the tenancy market. In the first group of measures, we can highlight the reduction in the term of protection against eviction in favor of the tenant (which gets reduced from 5 to 3 years) and the greater freedom to determine the rent paid in the contract (which will not be necessarily linked to the increase in the CPI anymore). ${ }^{2}$ With regard to the tax measures, the package encourages the creation of REITs. Finally, the latest reform package (July 2012) adopted a VAT rate on the purchase of new housing of $10 \%$ (rather than the rate of $4 \%$ applied until then) beginning in January 2013 and eliminated the deduction for house purchase for transactions taking place after January 2013.

The potential effects of the abrogation of the deduction are very significant. It was repeatedly required by international institutions such as the European Commission (2012) in its assessment of the National Reform Programme of 2012 of Spain, the IMF (2012) in its Article IV consultation or the OECD in its Economic Surveys of Spain (2010 and previous surveys). In fact, the OECD (2012) welcomed the abrogation of the deduction for home purchase (not effective yet at that time) in its Economic Survey of 2012. All those institutions have always required reducing the bias caused by the tax system in favour of homeownership (versus the rental market) more in general. The deduction itself had also focused the attention of the academia, which had criticized that it had undesirable redistributive effects (Sanz 2000 or Bilbao Terol et al. 2006) or that it increased housing prices (López-García, 2004) or that it favoured buying versus renting (López-García, 1996, García-Vaquero and Martínez, 2005, FEDEA, 2009, LópezGarcía, 2010 and all the previous references). At the academic level, following the abrogation of the deduction in January 2013, the debate is now focused on the discussion of whether the abrogation should also have been applied retroactively (this discussion clearly exceeds the scope of this paper). ${ }^{3}$

The aim of this paper is to assess the macroeconomic effects of some of the housing market reforms passed in Spain in 2012. In particular, in addition to the increase in VAT, we can highlight the long awaited abrogation of the deduction for home purchase. In order to do that, we use a small-open economy dynamic stochastic general equilibrium (DSGE) model calibrated to capture the key ratios of the Spanish economy. The model includes a housing market, covering both the rental market side and the property market side and credit-constrained agents. The model follows Ortega, Rubio and Thomas (2011), which is a valid framework to study housing markets in Spain, but appropriately modified to ensure the evaluation

\footnotetext{
${ }^{2}$ These reforms finally came into force in June 2013, with the approval of the Law 4/2013. See Mora-Sanguinetti (2013) for a first analysis of these rental market reforms in Spain.

${ }^{3}$ Most probably, the committee of experts (comité de sabios) developing the tax reform proposal for Spain in 2014 will introduce, among its recommendations, the total (and retroactive) abrogation of the deduction.
} 
of the most recent reforms. In particular, this model explicitly includes the existence of possible fiscal incentives to housing purchases which would reduce the effective price of housing. Likewise, we introduce a tax that would be a proxy for the VAT charged on new home purchases. In the model, the government maintains a balanced budget period by period. The novel contribution of this paper lies on the policy side. Results show that both measures increase the proportion of rental housing but at the expense of a negative impact on economic activity. More specifically, both measures reduce the activity of the construction sector and reduce real housing prices. The effects are stronger in the case of the abrogation of the deduction for home purchase than in the case of the VAT increase.

The paper is structured as follows: Section 2 presents the DSGE model used to simulate the impact of the measures analyzed, Section 3 shows the dynamics of the model, Section 4 provides the results of the simulations and finally, Section 5 concludes.

\section{Model setup}

In order to appropriately capture the Spanish structure, we consider a small-open economy inside a monetary union. We denote the home country by A and the rest of the union by B. In the home country, there are savers and borrowers which differ in their discount factors. Savers consume goods produced domestically and abroad, derive utility from housing, and work. They can also trade financial assets both domestically and internationally. Countries are in a monetary union in which the euro is the common currency, therefore assets are denominated in euros and there is no need for an exchange rate system. As in Iacoviello (2005), borrowers are more impatient than savers and need collateral to obtain loans. There are two production sectors: the construction sector and the consumption goods sector. For simplicity, housing is a non-tradable good. Consumption goods prices are sticky. As in Ortega, Rubio and Thomas (2011), houses can be bought or rented. In order to study the recent reforms in Spanish housing markets, there are both fiscal incentives to house purchases and a VAT tax applied to new homes. We assume that subsidies are financed by distortionary taxes; in particular, we consider a tax on wage income. ${ }^{4}$ Monetary policy is conducted by a single central bank and fiscal policy is implemented at the country level. ${ }^{5}$

\footnotetext{
${ }^{4}$ This is a positive paper, welfare implications are not analysed. In order to determine which fiscal consolidation scheme would be more efficient for the economy a welfare analysis should be made. We leave this for further research.

${ }^{5}$ In this paper, for simplicity, we consider borrowers and savers within the country, we abstract from the issue that there might be a geographical division between borrowers and savers.
} 


\subsection{Savers}

Savers in Country A choose consumption, housing and labor in order to maximize

$$
W_{0}^{s}=E_{0} \sum_{t=0}^{\infty}\left(\beta^{s}\right)^{t}\left(\log C_{t}^{s}+\vartheta \log H_{t}^{s}-\frac{\left(L_{t}^{s}\right)^{1+\eta}}{1+\eta}\right)
$$

where $\beta^{s}$ is the savers' discount factor, $\vartheta$ is the weight of utility from housing services, $H_{t}^{s}$ is savers' stock of owner-occupied housing, and $L_{t}^{s}$ is a composite of labor supply to the consumption sector $\left(L_{c t}^{s}\right)$ and the housing sector $\left(L_{h t}^{s}\right)$,

$$
L_{t}^{s}=\left[\omega_{l}^{1 / \varepsilon_{l}}\left(L_{c t}^{s}\right)^{\left(1+\varepsilon_{l}\right) / \varepsilon_{l}}+\left(1-\omega_{l}\right)^{1 / \varepsilon_{l}}\left(L_{h t}^{s}\right)^{\left(1+\varepsilon_{l}\right) / \varepsilon_{l}}\right]^{\varepsilon_{l} /\left(1+\varepsilon_{l}\right)}
$$

where $\omega_{l}$ is a weight parameter and $\varepsilon_{l}$ is the elasticity of substitution between labor types. Savers consume a basket of domestically and foreign produced goods, given by

$$
C_{t}^{s}=\left(C_{A t}^{s}\right)^{\xi}\left(C_{B t}^{s}\right)^{1-\xi}
$$

where $C_{j t}^{s}$ are Dixit-Stiglitz aggregators of consumption goods varieties produced in country $j=A, B$, and $\xi>0$ measures the degree of home bias in consumption. The household's nominal budget constraint is given by

$$
\begin{gathered}
P_{A t} C_{A t}^{s}+P_{B t} C_{B t}^{s}+Q_{t}^{h}\left[\left(1-\tau_{h}\right)(1+V A T)\left(H_{t}^{s}-(1-\delta) H_{t-1}^{s}\right)+\left(H_{t}^{z}-(1-\delta) H_{t-1}^{z}\right)\right]+B_{t}+D_{t}= \\
\left(1-\tau_{w t}\right)\left(W_{c t} L_{c t}^{s}+W_{h t} L_{h t}^{s}\right)+Q_{t}^{z} Z_{t}+R_{A t-1} B_{t-1}+R_{t-1} \Gamma\left(\frac{-D_{t-1}}{P_{A t-1} Y_{t-1}}\right) D_{t-1}+P_{A t} F_{t}
\end{gathered}
$$

where $P_{A t}$ is the nominal price index of final consumption goods produced in Country A, $P_{B t}$ is the corresponding index for goods produced in Country B, $Q_{t}^{h}$ is the nominal price of houses, $\tau_{h}$ is the deduction on purchases of owner-occupied houses, $V A T$ is a value added tax rate on housing purchases, $B_{t}$ and $D_{t}$ are domestic and foreign nominal debt held by savers, respectively, $\tau_{w t}$ is the time-varying tax rate on wage income, $W_{c t}$ and $W_{h t}$ are nominal wages in the consumption goods and the housing sector, respectively, $R_{A t}$ is the nominal interest rate on domestic bonds, and $R_{t}$ is the nominal ECB rate. In order to ensure stationarity of equilibrium, we follow Schmitt-Grohe \& Uribe (2001) and assume that domestic agents pay a risk premium $\Gamma$ which is strictly increasing in the country's net foreign debt to output ratio, $\left(-D_{t}\right) /\left(P_{A t} Y_{t}\right)$. We assume that the risk-premium takes the form $\Gamma(x)=e^{\psi x}$, with $\psi>0$. 
$F_{t}$ are firms' real profits rebated to savers every period. Savers use a certain part of their housing stock, which we denote by $H_{t}^{z}$, to produce rental services $Z_{t}$ according to the production function $Z_{t}=A_{z} H_{t}^{z}$. The parameter $A_{z}$ measures the efficiency of the rental market and will serve as a proxy of the efficiency of institutions to enforce rental contracts. Rental services are sold competitively to borrowers at a unit nominal price $Q_{t}^{z}$. The parameter $\delta$ is the depreciation rate of houses. We can rewrite the budget constraint in terms of producer prices in Country A,

$$
\begin{aligned}
C_{A t}^{s} & +p_{B t} C_{B t}^{s}+q_{t}^{h}\left[\left(1-\tau_{h}\right)(1+V A T)\left(H_{t}^{s}-(1-\delta) H_{t-1}^{s}\right)+\left(H_{t}^{z}-(1-\delta) H_{t-1}^{z}\right)\right]+b_{t}+d_{t} \\
& =\left(1-\tau_{w t}\right)\left(w_{c t} L_{c t}^{s}+w_{h t} L_{h t}^{s}\right)+q_{t}^{z} A_{z} H_{t}^{z}+\frac{R_{A t-1} b_{t-1}}{\Pi_{A t}}+\frac{R_{t-1} e^{\psi\left(-d_{t-1}\right) / Y_{t-1}} d_{t-1}}{\Pi_{A t}}+F_{t},
\end{aligned}
$$

where $\Pi_{A t} \equiv P_{A t} / P_{A t-1}$ denotes domestic PPI inflation, $p_{B t} \equiv P_{B t} / P_{A t}$ is the price of foreign goods in terms of home goods (that is, the terms of trade), $q_{t}^{h} \equiv Q_{t}^{h} / P_{A t}$ and $q_{t}^{z} \equiv Q_{t}^{z} / P_{A t}$ denote real house prices and real rental rates, respectively, $w_{c t}$ and $w_{h t}$ are real wages in each sector, and we have defined $b_{t} \equiv B_{t} / P_{A t}$ and $d_{t} \equiv D_{t} / P_{A t}$. The first order conditions of the maximization problem are the following,

$$
\begin{gathered}
\frac{C_{A t}^{s}}{C_{B t}^{s}}=\left(\frac{\xi}{1-\xi}\right) p_{B t} \\
\frac{\vartheta}{H_{t}^{s}}=\left(1-\tau_{h}\right)(1+V A T)\left(\frac{q_{t}^{h}}{C_{A t}^{s} / \xi}-\beta^{s} E_{t} \frac{q_{t+1}^{h}(1-\delta)}{C_{A t+1}^{s} / \xi}\right), \\
\frac{1}{C_{A t}^{s}}=\beta^{s} E_{t} \frac{1}{C_{A t+1}^{s}} \frac{R_{A t}}{\Pi_{A t+1}}, \\
\left(1-\tau_{w t}\right) \frac{w_{c t}}{C_{A t}^{s} / \xi}=\left(L_{t}^{s}\right)^{\eta} \omega_{l}^{1 / \varepsilon_{l}}\left(\frac{L_{c t}^{s}}{L_{t}^{s}}\right)^{1 / \varepsilon_{l}} \\
\left(1-\tau_{w t}\right) \frac{w_{h t}}{C_{A t}^{s} / \xi}=\left(L_{t}^{s}\right)^{\eta}\left(1-\omega_{l}\right)^{1 / \varepsilon_{l}}\left(\frac{L_{h t}^{s}}{L_{t}^{s}}\right)^{1 / \varepsilon_{l}} \\
\frac{q_{t}^{h}}{C_{A t}^{s}}=\frac{q_{t}^{z} A_{z}}{C_{A t}^{s}}+\beta^{s} E_{t} \frac{(1-\delta) q_{t+1}^{h}}{C_{A t+1}^{s}}
\end{gathered}
$$

Equation (1) equates relative prices to the marginal rate of substitution between the goods produced in Countries A and B. Equation (2) is the first order condition for owner-occupied housing, which equates the marginal utility of housing services to the effective (i.e. subsidy and VAT-adjusted) user cost of housing. Equation (3) is the Euler Equation for domestic bonds. Equation (4) follows from no arbitrage 
between domestic and foreign bonds. Equations (5) and (6) are the first order conditions for labor supply in the consumption and housing sector, respectively. Equation (7) is the first order condition for house purchases for production of rental services.

\subsection{Borrowers}

Borrowers have a discount factor $\beta^{b}<\beta^{s}$ and maximize

$$
W_{0}^{b}=E_{0} \sum_{t=0}^{\infty}\left(\beta^{b}\right)^{t}\left(\log C_{t}^{b}+\vartheta \log \tilde{H}_{t}^{b}-\frac{\left(L_{t}^{b}\right)^{1+\eta}}{1+\eta}\right)
$$

where $C_{t}^{b}=\left(C_{A t}^{b}\right)^{\xi}\left(C_{B t}^{b}\right)^{1-\xi}$ is a consumption basket,

$$
L_{t}^{b}=\left[\omega_{l}^{1 / \varepsilon_{l}}\left(L_{c t}^{b}\right)^{\left(1+\varepsilon_{l}\right) / \varepsilon_{l}}+\left(1-\omega_{l}\right)^{1 / \varepsilon_{l}}\left(L_{h t}^{b}\right)^{\left(1+\varepsilon_{l}\right) / \varepsilon_{l}}\right]^{\varepsilon_{l} /\left(1+\varepsilon_{l}\right)}
$$

is a composite of labor services in both sectors analogous to that of savers and

$$
\tilde{H}_{t}^{b}=\left[\omega_{h}^{1 / \varepsilon_{h}}\left(H_{t}^{b}\right)^{\left(\varepsilon_{h}-1\right) / \varepsilon_{h}}+\left(1-\omega_{h}\right)^{1 / \varepsilon_{h}}\left(Z_{t}\right)^{\left(\varepsilon_{h}-1\right) / \varepsilon_{h}}\right]^{\varepsilon_{h} /\left(\varepsilon_{h}-1\right)}
$$

is a composite of housing services provided by owner-occupied and rented houses, where $H_{t}^{b}$ is borrowers' stock of owned houses and $Z_{t}$ are rental services. Therefore, borrowers derive utility both from living in owner-occupied houses and in rented houses. ${ }^{6}$ Maximization is subject to the following budget constraint, written in terms of domestic producer prices,

$$
\begin{gathered}
C_{A t}^{b}+p_{B t} C_{B t}^{b}+q_{t}^{h}\left(1-\tau_{h}\right)(1+V A T)\left[H_{t}^{b}-(1-\delta) H_{t-1}^{b}\right]+q_{t}^{z} Z_{t}+\frac{R_{A t-1} b_{t-1}}{\Pi_{A t}} \\
=\left(1-\tau_{w t}\right)\left(w_{c t} L_{c t}^{b}+w_{h t} L_{h t}^{b}\right)+b_{t},
\end{gathered}
$$

\footnotetext{
${ }^{6}$ This does not literally mean that each borrower lives simultaneously in an owned house and in a rented house. Instead, our interpretation is that there exists a large representative borrower-type household with a continuum of members, some of which live in owner-occupied houses and the rest of which live in rented houses. Our composite index in equation (9) thus represents the aggregate preferences of all household members with respect to each kind of housing services. As an alternative modelling approach, Gervais (2002) considers a framework where agents decide endogenously whether to buy a house or rent.

On the other hand, notice that savers do not demand rental housing services, unlike the case of borrowers. We do this for simplicity. However, results not reported here but available upon request show that, under the assumption of homogeneous preferences across savers and borrowers, our quantitative results are only marginally affected.
} 
Borrowers are also subject to a collateral constraint which limits the amount of borrowing (gross of interest payments) to a fraction $m$ of the expected resale value of their houses, ${ }^{7}$

$$
b_{t} \leq \frac{m}{R_{A t}} E_{t} \Pi_{A t+1} q_{t+1}^{h} H_{t}^{b} .
$$

The first order conditions of this problem are the following,

$$
\begin{gathered}
\frac{C_{A t}^{b}}{C_{B t}^{b}}=\frac{\xi}{1-\xi} p_{B t}, \\
\frac{\xi}{C_{A t}^{b}}=\beta^{b} E_{t} \frac{\xi}{C_{A t+1}^{b}} \frac{R_{A t}}{\Pi_{A t+1}}+\lambda_{t} \\
\left(1-\tau_{w t}\right) \frac{w_{c t}}{C_{A t}^{b} / \xi}=\left(L_{t}^{b}\right)^{\eta}\left(\frac{\omega_{l} L_{c t}^{b}}{L_{t}^{b}}\right)^{1 / \varepsilon_{l}}, \\
\left(1-\tau_{w t}\right) \frac{w_{h t}}{C_{A t}^{b} / \xi}=\left(L_{t}^{b}\right)^{\eta}\left(\frac{\left(1-\omega_{l}\right) L_{h t}^{b}}{L_{t}^{b}}\right)^{1 / \varepsilon_{l}}, \\
\frac{\vartheta}{\tilde{H}_{t}^{b}}\left(\frac{\omega_{h} \tilde{H}_{t}^{b}}{H_{t}^{b}}\right)^{1 / \varepsilon_{h}}=\left(1-\tau_{h}\right)(1+V A T)\left(\frac{q_{t}^{h}}{C_{A t}^{b} / \xi}-\beta^{b} E_{t} \frac{q_{t+1}^{h}(1-\delta)}{C_{A t+1}^{b} / \xi}\right)-\lambda_{t} m E_{t} q_{t+1}^{h} \frac{\Pi_{A t+1}}{R_{A t}}, \\
\frac{\tilde{H}_{t}^{b}}{\left(\frac{\left(1-\omega_{h}\right) \tilde{H}_{t}^{b}}{Z_{t}}\right)^{1 / \varepsilon_{h}}}=\frac{q_{t}^{z}}{C_{A t}^{b} / \xi} .
\end{gathered}
$$

where $\lambda_{t}$ is the Lagrange multiplier on the collateral constraint. These first order conditions are interpreted analogously to the ones of savers. An important difference is the demand for owner-occupied housing, equation (16). The latter equates the marginal utility of owner-occupied housing to the effective user cost of housing minus the marginal collateral value of housing. Therefore, ceteris paribus, an increase in the collateral value of housing (due for instance to an expected increase in house prices) has a positive effect on borrowers' demand for owner-occupied housing.

\footnotetext{
${ }^{7}$ The fact that borrowers are more impatient than savers guarantees that the collateral constraint is binding in the steady state. Provided the shocks to the economy are small enough, the constraint also binds over the business cycle.
} 


\subsection{Firms}

\subsubsection{Construction firms}

New homes are produced using the following technology,

$$
I H_{t}=L_{h t}^{s}+L_{h t}^{b}
$$

where $I H_{t}$ is residential investment, $L_{h t}^{s}$ and $L_{h t}^{b}$ are savers' and borrowers' supply of labor in the housing sector, respectively. Free entry in the construction sector implies the following zero profit condition,

$$
w_{h t}=q_{t}^{h} .
$$

\subsubsection{Intermediate good producers}

The intermediate good market is perfectly competitive. The homogenous intermediate good is produced according to the following technology,

$$
Y_{t}=L_{c t}^{s}+L_{c t}^{b}
$$

where $L_{c t}^{s}$ and $L_{c t}^{b}$ are savers' and borrowers' supply of labor in the consumption goods sector, respectively. Free entry in this sector implies the following zero profit condition,

$$
w_{c t}=p_{t}^{I}
$$

where $p_{t}^{I}$ is the real price of the intermediate good, that is, the real marginal cost for final consumption goods producers.

\subsubsection{Final consumption goods producers}

Final consumption goods are produced by a continuum of monopolistically competitive firms. Prices in the final goods sector are set in a staggered fashion according to the Calvo (1983) mechanism. This implies the following (log-linear approximation of the) New Keynesian Phillips Curve for domestic PPI inflation,

$$
\log \Pi_{A t}=\beta^{s} \log \Pi_{A t+1}+\frac{(1-\theta)\left(1-\theta \beta^{s}\right)}{\theta} \log \left(p_{t}^{I} \frac{\varepsilon_{p}}{\varepsilon_{p}-1}\right)
$$


where $\theta$ is the probability of firms not changing prices, $\varepsilon_{p}$ is the elasticity of substitution across final goods, and $\varepsilon_{p} /\left(\varepsilon_{p}-1\right)$ is the steady-state markup.

\section{$2.4 \quad$ Fiscal policy}

For simplicity, we assume that the government balances its budget period by period. That is,

$$
\tau_{w t}\left[w_{c t}\left(L_{c t}^{s}+L_{c t}^{b}\right)+w_{h t}\left(L_{h t}^{s}+L_{h t}^{b}\right)\right]=\left(\tau_{h}-V A T\right) q_{t}^{h}\left[H_{t}^{s}-(1-\delta) H_{t-1}^{s}+H_{t}^{b}-(1-\delta) H_{t-1}^{b}\right] .
$$

Therefore, the government levies taxes on wage income in order to finance its subsidies to rental payments and to house purchases.

\subsection{Market clearing and international linkages}

Housing market clearing implies $H_{t}=H_{t}^{s}+H_{t}^{z}+H_{t}^{b}$, where the total supply of houses evolves according to $H_{t}=I H_{t}+(1-\delta) H_{t-1}$. Combining the latter two conditions, we have that

$$
I H_{t}=H_{t}^{s}-(1-\delta) H_{t-1}^{s}+H_{t}^{z}-(1-\delta) H_{t-1}^{z}+H_{t}^{b}-(1-\delta) H_{t-1}^{b}
$$

The aggregate resource constraint for domestically-produced consumption goods can be expressed as

$$
Y_{t}=C_{A t}^{s}+C_{A t}^{b}+\xi^{*} p_{B t} c_{t}^{*}
$$

where $c_{t}^{*}$ is aggregate consumption in the rest of the monetary union and $\xi^{*}$ is a foreign preference parameter. For future reference, we define real gross domestic product as $G D P_{t} \equiv Y_{t}+q_{t}^{h} I H_{t}$. Terms of trade evolve according to

$$
p_{B t}=\frac{\Pi_{B t}}{\Pi_{A t}} p_{B, t-1}
$$

where $\Pi_{B t}$ is both PPI and CPI inflation in the rest of the union. ${ }^{8}$ The ECB nominal interest rate follows a Taylor rule that responds smoothly to deviations of EMU-wide inflation from its long-run target (which we normalize to 1 ),

$$
R_{t}=(1 / \beta)^{1-\phi_{R}} R_{t-1}^{\phi_{R}} \Pi_{B t}^{\left(1+\phi_{\Pi}\right)\left(1-\phi_{R}\right)} \exp \left(e_{R, t}\right)
$$

where $\phi_{R}$ is a smoothing parameter, $\phi_{\Pi}$ captures the policy response to inflation, and $e_{R, t}$ is an iid shock.

\footnotetext{
${ }^{8}$ Remember that the home country is assumed to be small relative to the rest of the monetary union.
} 
The home country's net foreign asset position (per capita) follows

$$
d_{t}=\frac{R_{t-1} e^{\psi\left(-d_{t-1}\right) / Y_{t-1}}}{\Pi_{A t}} d_{t-1}+Y_{t}-C_{A t}^{s}-C_{A t}^{b}-p_{B t}\left(C_{B t}^{s}+C_{B t}^{b}\right)
$$

The model can be closed by means of two equations that determine foreign consumption demand $\left(c_{t}^{*}\right)$ and foreign inflation $\left(\Pi_{B t}\right)$. We assume for simplicity that both variables (in logs) follow $\mathrm{AR}(1)$ processes, with means normalized to zero.

\section{Dynamics}

\subsection{Calibration}

For calibration, we follow Ortega, Rubio and Thomas (2011) to match the ratios of the model with the key average ratios found for the Spanish economy, mostly for the period 1997-2008. ${ }^{9}$ The home bias parameter, $\xi$, is set to match the share of Spanish goods in private consumption, which in the model is exactly equal to $\xi .{ }^{10}$ The efficiency in the production of rental services, $A_{z}$, is chosen to replicate the rent-to-house-price ratio, given by $q^{z} / q^{h}=\left(1-\beta^{s}(1-\delta)\right) / A_{z}$ in the model's steady state. Notice that the latter two steady-state ratios are invariant to changes in housing subsidies and taxes $\left(\tau_{h}\right.$, $V A T)$. The relative weight on utility from housing services, $\vartheta$, and the weight parameters in the CES baskets of labor supply and housing services, $\omega_{l}$ and $\omega_{h}$ respectively, are jointly chosen by minimizing the sum of square distances between four steady-state ratios in the model and their corresponding data counterparts. These ratios are the shares of rented houses and mortgaged houses in the aggregate housing stock, $H^{z} / H$ and $H^{b} / H$ respectively, the share of residential investment in GDP, $q^{h} I H / G D P$, and the share of construction in total employment, $L_{h} /\left(L_{c}+L_{h}\right)$, where $L_{i} \equiv L_{i}^{s}+L_{i}^{b}$ is total labor in sector $i=c, h$. The values for these parameters, together with all other parameters, are reported in Table 1, whereas the resulting model steady-state ratios are compared to their data counterparts in Table 2.

\footnotetext{
${ }^{9}$ Notice that, even though the EMU regime started in 1999, by 1997 EMU membership was anticipated by most agents, and in practice Spain had fixed exchange rate with respect to the rest of the EMU in that period.

${ }^{10}$ The foreign preference parameter is set such that terms of trade in the steady state are normalized to one, producing $\xi^{*}=1.256$.
} 


\begin{tabular}{|c|c|c|}
\hline$\beta^{s} / \beta^{b}$ & $0.99 / 0.97$ & Discount factor of savers / borrowers \\
\hline$\vartheta$ & 0.143 & Relative weight on utility from housing services \\
\hline$\omega_{l}$ & 0.214 & Weight parameter in labor services aggregator \\
\hline$\omega_{h}$ & 0.787 & Weight parameter in housing services aggregator \\
\hline$\varepsilon_{l}$ & 1 & Elasticity of substitution between labor types \\
\hline$\varepsilon_{h}$ & 2 & Elasticity of substitution between home ownership and rent \\
\hline$\eta$ & 0.01 & Inverse elasticity of labor supply \\
\hline$\varepsilon_{p}$ & 6 & Elasticity of substitution among final goods \\
\hline$\xi$ & 0.663 & Home bias in consumption \\
\hline$A_{z}$ & 1.621 & Efficiency in production of rental housing services \\
\hline$\delta$ & 0.01 & Depreciation rate of the housing stock \\
\hline$m$ & 0.70 & Loan-to-value ratio \\
\hline$\theta$ & 0.75 & Calvo parameter \\
\hline$\tau_{h}$ & 0.15 & Subsidy rate house purchases for owner occupation \\
\hline$V A T$ & 0.04 & VAT rate for house purchases \\
\hline$\phi_{R}$ & 0.8 & Coefficient on lagged nominal interest rate in the Taylor rule \\
\hline$\phi_{\Pi}$ & 1.5 & Coefficient on area-wide inflation in the Taylor rule \\
\hline$\psi$ & 0.01 & Elasticity of risk premium with respect to net foreign asset position \\
\hline
\end{tabular}

Table 2: Steady-State Ratios of the Spanish Economy

\begin{tabular}{lccc}
\hline \hline & Data & Model & Data Sources \\
Housing rental Share & 0.122 & 0.139 & INE, Censo de Población y Vivienda 2001 \\
$\begin{array}{l}\text { Share of housing with mortgage } \\
\text { Rent over housing price }\end{array}$ & 0.305 & 0.322 & Asociación Española de Banca, 2003-2008 \\
$\begin{array}{l}\text { Residential investment / GDP } \\
\text { Construction labor share }\end{array}$ & 0.073 & 0.073 & Ministerio de Vivienda, 1997-2008 \\
\begin{tabular}{l} 
Share home goods in consumption \\
\hline \hline
\end{tabular} & 0.663 & 0.663 & Spanish National Accounts, 1997-2008 \\
\hline
\end{tabular}

This way, as shown in Table 2, the model reproduces the average proportion of residential investment over GDP, $7.3 \%$, as well as the weight of employment in construction over total employment (13.8\%). 
The rental share in the model is $13.9 \%$ (slightly above $12,2 \%$, found in the data) ${ }^{11}$. The share of housing with mortgages is $32.2 \%$ in the model (also slightly above the average found in the period 1997-2008, $30.5 \%)$.

The remaining parameters are set to standard values in the literature. For savers, we use a discount factor that corresponds to an annual interest rate of $4 \%$. For borrowers, we use a slightly lower discount factor, in line with the literature on DSGE models with housing and financial frictions. Following Horvath (2000), we set the elasticity of substitution between labor types, $\varepsilon_{l}$, to one. For the elasticity of substitution between services from home ownership and rent, $\varepsilon_{h}$, unfortunately there are no reliable estimates in the literature. We take the value of 2 as our baseline in order to make households more sensitive to the relative price of houses and rents than would be the case under lower values. Ortega et al. (2011) perform a sensitivity analysis for this parameter and find that the qualitative results are largely unaffected by this parameter. We choose the inverse elasticity of labor supply, $\eta$, following Iacoviello (2005). ${ }^{12}$ The value for the elasticity of substitution among final goods, $\varepsilon_{p}$, implies a markup of $20 \%$ in the steady state, a value commonly found in the literature. ${ }^{13}$ We set the housing depreciation rate to 0.01, as in Iacoviello and Neri (2010). We use 0.70 for the loan-to-value ratio, consistently with data from the European Mortgage Federation (Spain Factsheet 2009). ${ }^{14}$ The probability of not changing prices, $\theta$, is set to 0.75 , implying that prices change every four quarters on average. The coefficients in the Taylor Rule are set to 0.8 for the lagged interest rate and 1.5 for inflation, as proposed by Taylor (1993). The elasticity of the international risk-premium, $\psi$, is set to a standard value of 0.01 . The subsidy for house purchases in Spain is set to $\tau_{h}=0.15$, consistently with the current $15 \%$ income tax deduction for house purchases. The $V A T$ rate is initially set to $4 \%$.

\section{Policy Evaluation}

\subsection{Simulations}

Of all the reforms outlined in the introduction, we are going to focus on the fiscal measures. The model includes a subsidy for house purchase, as a proxy for the deduction for home purchase, that we calibrate at $15 \%$. In addition, the model also includes a VAT tax applicable for new house purchases

\footnotetext{
${ }^{11}$ Censo de población y vivienda, INE, 2001.

${ }^{12}$ This value implies a virtually flat labor supply curve, higher than microeconomic estimates but rationalizing the weak observed response of real wages to macroeconomic disturbances.

${ }^{13}$ See for instance Blanchard and Galí (2008).

${ }^{14}$ The actual value published by the European Mortgage Federation is $67.5 \%$.
} 
that we calibrate at $4 \%$. Therefore, the simulations we perform are the following: First, we simulate separately (thus allowing us to isolate the effect of each measure) the effects of eliminating the subsidy for homeownership (from 15\% to 0\%) and the VAT increase on the purchase of new homes (from $4 \%$ to $10 \%)$. Second, we jointly simulate the rise in the VAT rate and the abrogation of the deduction for home purchases, while both measures have been implemented jointly from January 2013. In the simulations, it is assumed that the two measures are permanent and that their application is immediate (as in fact it was the case).

Changes in the tax system affect the new housing effective user cost. Therefore, this has an impact on housing demand and supply, which determine house prices. In turn, changes in house prices have an effect on the value of collateral for borrowers, which affects their borrowing capacity and ultimately their consumption. In this way, these fiscal measures are transmitted to the macroeconomy.

Note that both measures generate tax savings. To determine the net effect on the economy of the reform as a whole it is important to determine how those savings are used. The model incorporates two assumptions about their use. First, as noted above, the government maintains a balanced budget. Second, the fiscal mechanism used to balance the budget is a tax on labor income. Thus, tax savings originated by the two measures are used to reduce other distortionary taxes. ${ }^{15}$

As for the reform measures in the rental market (the reduction in the term of protection of the tenant against eviction and the liberalization of the rents), it is difficult to evaluate them rigorously inside a DSGE model given its structure. Note that the model includes a technological parameter, $A_{z}$, that approximates the efficiency of the functioning of the rental market. This parameter would thus include everything related to the institutional design of the market, such as the regulation or the quality of the enforcement institutions, however it is not possible to quantify to what extent the parameter would change as a result of the implementation of the most recent reforms.

\subsection{Results}

The following tables show the effects on a number of macroeconomic variables of both the increase in the VAT rate on new housing purchases (from 4 to 10\%) and the abrogation of the deduction for home purchases. Tables 3 and 4 display the isolated effect of each measure, while Table 5 shows the joint effect

\footnotetext{
${ }^{15}$ In the model, the deduction for home purchase is set as a percentage of the value of the dwelling and it is received in full and instantaneously at the time of purchase. However, in reality, the buyer benefits from it all over the period of repayment of the mortgage (with a maximum deduction each year of repayment). This means that in the model, the reduction in public spending due to the abrogation of the subsidies is faster than expected. This in turn affects the reduction in the tax on wage income.
} 
of both measures. In each case, we can see the average annual effects during the first four years after the measures take place (short and medium run), as well as the long-run effects, once the economy has reached the new steady state.

In the model, both the tax deduction removal and the VAT increase have similar qualitative effects. Both measures imply, ceteris paribus, an increase in the new housing effective user cost. Thus, households decrease their housing demand and this, in turn, reduces residential investment. The shrink in the construction sector contracts GDP and total employment, especially in the short run, while the effects gradually fade out in the long run.

The fall in housing demand makes housing prices decrease very sharply in the short run. In the long run, housing prices fall $7.5 \%$ in the case of the subsidy removal, and $2.8 \%$ for the VAT increase. Given that houses are an asset that serve as collateral for borrowing, this decrease in housing prices means that collateral is worth less and borrowers are more limited to access credit markets. ${ }^{16}$ Therefore, borrowers are able to consume and invest less. This wealth effect amplifies the negative implications of both measures through a financial accelerator mechanism.

\begin{tabular}{cccccc}
\hline \hline Table 3: VAT Increase & Year 1 & Year 2 & Year 3 & Year 4 & Long Run \\
GDP, \% & -0.21 & -0.23 & -0.22 & -0.21 & -0.03 \\
Employment, \% & -0.47 & -0.50 & -0.49 & -0.47 & -0.21 \\
Construction over GDP, pp & -0.54 & -0.54 & -0.53 & -0.52 & -0.36 \\
\% Employment on Construction, pp & -0.48 & -0.50 & -0.49 & -0.48 & -0.33 \\
Real Housing Price, \% & -4.29 & -4.21 & -4.13 & -4.04 & -2.79 \\
\% Rental Sector, pp & 1.95 & 1.95 & 1.94 & 1.93 & 1.90 \\
\% Houses with mortgages, pp & -2.02 & -2.00 & -2.00 & -1.99 & -1.94 \\
\hline \hline
\end{tabular}

\footnotetext{
${ }^{16}$ The model assumes that housing is used as collateral, not only for mortgages but also for consumption loans. This is less common in Spain than in anglosaxon countries, where this "mortgage equity withdrawal" is more popular.
} 


\begin{tabular}{cccccc}
\hline \hline Table 4: Deduction Removal & Year 1 & Year 2 & Year 3 & Year 4 & Long Run \\
GDP, \% & -0.84 & -0.67 & -0.61 & -0.57 & -0.08 \\
Employment, \% & -1.61 & -1.41 & -1.33 & -1.27 & -0.57 \\
Construction over GDP, pp & -1.45 & -1.39 & -1.36 & -1.34 & -0.94 \\
\% Employment on Construction, pp & -1.40 & -1.33 & -1.30 & -1.27 & -0.88 \\
Real Housing Price, \% & -11.48 & -11.16 & -10.91 & -10.69 & -7.45 \\
\% Rental Sector, pp & 5.94 & 5.91 & 5.91 & 5.90 & 5.78 \\
\% Houses with mortgages, pp & -5.63 & -5.58 & -5.57 & -5.56 & -5.37 \\
\hline \hline
\end{tabular}

\begin{tabular}{cccccc}
\hline \hline Table 5: Both Measures & Year 1 & Year 2 & Year 3 & Year 4 & Long Run \\
GDP, \% & -1.29 & -0.92 & -0.81 & -0.74 & -0.09 \\
Employment, \% & -2.32 & -1.86 & -1.72 & -1.64 & -0.73 \\
Construction over GDP, pp & -1.88 & -1.77 & -1.73 & -1.70 & -1.21 \\
\% Employment on Construction, pp & -1.90 & -1.71 & -1.67 & -1.64 & -1.14 \\
Real Housing Price, \% & -14.84 & -14.35 & -14.01 & -13.73 & -9.60 \\
\% Rental Sector, pp & 8.17 & 8.14 & 8.13 & 8.12 & 7.95 \\
\% Houses with mortgages, pp & -7.40 & -7.35 & -7.34 & -7.32 & -7.06 \\
\hline \hline
\end{tabular}

On the other hand, there is a substitution effect. Now, in relative terms, the owner-occupied housing user cost increases with respect to the one of rentals. Thus, after these measures are applied, renting is comparatively more attractive than purchasing. In this way, after the subsidy removal, the rental market share increase is about 5.8 p.p. in the long run. The VAT measure implies an increase of 1.9 p.p. in the rental market share.

Finally, in both cases, the government increases its revenues. Therefore, to keep the budget balanced, as assumed in the model, the labor income taxes decrease. ${ }^{17}$ This increases the labor supply and in turn consumption goods production. Then, this increase in production partially offsets the fall in construction. Overall, this limits the total GDP decrease, especially in the long run, where GDP falls less than $0.1 \%$ in all cases. ${ }^{18}$

\footnotetext{
${ }^{17}$ Recall that in the model the fiscal saving due to the subsidy removal happens at a faster pace than in reality. Therefore, the effects on the labor income taxes are more realistic in the long run than in the short/medium run.

${ }^{18}$ This beneficial effect on GDP happens because of the introduction of distortionary taxes. If the model included lump-sum taxes in order to balance the budget, the negative long-run effects on GDP would not be offset.
} 
Given that both measures have effects going in the same direction, when we jointly evaluate the policies, the argument is similar but with larger effects. The effects of both measures are accumulated. In this way, as shown in Table 5, the introduction of both measures at the same time as an effect on housing prices of $-9.6 \%$ in the long run, while the increase in the rental market is almost 8 p.p. The decrease in GDP is relatively large in the short run (1.3\% in the first year), and quite small in the long $\operatorname{run}(0.1 \%) \cdot{ }^{19}$

\section{Concluding remarks}

The housing market, even during the current recession, remains one of the sectors with the highest weight in the Spanish economy, both in terms of value added and number of hours worked. Therefore, a rigorous assessment of its performance is essential to analyze the functioning of the whole economy in Spain.

This paper evaluates the effects on the main macroeconomic variables of the Spanish economy of two alternative measures to reform the housing market: the abrogation of the deduction for home purchase and an increase in the VAT rate charged in the purchase of a new home. To do this we used an analytical framework consisting of a dynamic stochastic general equilibrium (DSGE) model that includes a housing market, with houses in both the rental and ownership sides, and credit-constrained agents. The model has been calibrated to reflect the key ratios of the Spanish economy.

This type of analysis, based on general equilibrium models is useful for understanding economic performance while models isolate the effect of a particular measure. More specifically, the models tell us which of the macroeconomic variables which characterizes an economy are most affected by a new policy measure and in what direction the changes will occur.

Results show that both measures increase the proportion of rental housing in the economy which is in line with the recommendations of international institutions (in this respect, see the previously cited reports of the European Commission, the IMF or the OECD). However, both measures have a negative impact on economic activity. More specifically, both measures reduce the activity of the construction sector implying a fall in total GDP and employment (this point is not always reflected in the previously cited academic papers for being sometimes partial equilibrium analyses). Both measures also reduce real housing prices (as discussed, this result is in line with what it was envisaged by López-García, 2004,

\footnotetext{
${ }^{19}$ Notice that in this paper we do not consider the reallocation of housing investment to other more productive activities. For a discussion on this issue, see Arce et al. (2008).
} 
for the case of the abrogation of the deduction for home purchase). The effects are more pronounced in the case of the abrogation of the deduction for home purchase than in the case of the VAT increase. Together, both measures accumulate their effects, since these effects go in the same direction. ${ }^{20}$

Facing the final effect of the measures on the economy as a whole, it is very important to evaluate how the fiscal revenues generated by these measures are used. Thus, under the assumption that greater fiscal savings created by the two measures are used to reduce distortionary taxes on wages, the consequent stimulation of labor supply and production of consumer goods would end up greatly limiting the negative effects on the GDP of the measures analyzed, especially in the long term.

In sum, the results of the model would suggest that the (long awaited) abrogation of the deduction for house purchase and the VAT increase would drive down housing prices and would have a negative impact on output and employment in the construction sector. However, in the long run, this negative impact could be offset by the beneficial effect of a reduction in distortionary taxes.

\footnotetext{
${ }^{20}$ We do not contemplate if the measures discussed in this paper should have been introduced retroactively. This is out of the scope of our research question.
} 


\section{References}

[1] Andrews D., Caldera Sánchez, A. and Å. Johansson (2011), "Housing Markets and Structural Policies in OECD Countries", OECD Economics Department Working Papers, 836, OECD Publishing.

[2] Arce, O., Campa, J. M., Gavilán, A., (2008), Asymmetric Collateral Requirements and Output Composition, Documentos de Trabajo n. ${ }^{o}$ 0837, Banco de España

[3] Arce, O., López-Salido, D. , (2011), "Housing Bubbles. American Economic Journal: Macroeconomics", 3 (1), pages 212-41.

[4] Bilbao Terol, C., García Valinas, M.A., Suarez Pandiello, J., (2006), "Intervenciones públicas, haciendas territoriales y precios de la vivienda", Papeles de Economía Española, 109, pages 237256.

[5] Blanchard, O., Galí, J., (2008), Labor Markets and Monetary Policy: A New-Keynesian Model with Unemployment, NBER Working Paper 13897

[6] Calvo, G., (1983), "Staggered prices in a utility-maximizing framework," Journal of Monetary Economics, Elsevier, 12(3), pages 383-398.

[7] ECB, (2003), Structural Factors in the EU Housing Markets, ECB Document

[8] EMF, (2008), A Review of Europe's Mortgage and Housing Markets, Hypostat 2008

[9] European Commission, (2012), Recommendation for a Council Recommendation on Spain's 2012 national reform programme and delivering a Council opinion on Spain's stability programme for 2012-2015, $\operatorname{COM}(2012) 310$ final.

[10] FEDEA (2009), "Por un mercado de la vivienda que funcione: una propuesta de reforma estructural", FEDEA, Madrid

[11] García-Vaquero, V. and J. Martínez (2005), "Fiscalidad de la vivienda en España", Documentos de Trabajo n. ${ }^{\circ}$ 0506, Banco de España

[12] Gervais, M., (2002), "Housing Taxation and Capital Accumulation", Journal of Monetary Economics, 49 (7), pages 1461-1489

[13] González-Páramo, J.M. and Onrubia, J. (1992), "El gasto pública en vivienda en España", Hacienda Pública Española, 120/121, 189-227.

[14] Horvath, M., (2000), "Sectoral Shocks and Aggregate Fluctuations", Journal of Monetary Economics, 45 (1), pages 69-106.

[15] Iacoviello, M., (2005), "House Prices, Borrowing Constraints and Monetary Policy in the Business Cycle", American Economic Review, Vol. 95, No. 3 (June), pages 739-764.

[16] Iacoviello, M, Neri, S., (2010), "Housing Market Spillovers: Evidence from an Estimated DSGE Model," AEJ Macro 
[17] IMF (2012), "Spain: 2012 Article IV Consultation”. IMF Country Report No. 12/202.

[18] López García, M. A., (1996), "Precios de la vivienda e incentivos fiscales a la vivienda en propiedad en España", Revista de Economía Aplicada, 12, pages 37-74.

[19] Lopez-Garcia, M. A. (2004). "Housing, prices and tax policy in Spain". Spanish Economic Review $6(1)$, pages $29-52$

[20] López García, M. A. (2010). "La Propuesta de reforma estructural del mercado de vivienda de FEDEA: una evaluación", Revista de Economia Aplicada 18(1), pages 153-175.

[21] Mora-Sanguinetti, J. S., (2012), "Is judicial inefficacy increasing the weight of the house property market in Spain? Evidence at the local level", SERIEs, Journal of the Spanish Economic Association 3 (3), pages 339-365.

[22] Mora-Sanguinetti, J. S. (2013), "Les causes de la faiblesse du marché du logement locatif en Espagne: Les effets de la réglementation, de la protection juridique et de la fiscalité", OFCE Revue 128, pages $218-243$.

[23] OECD (2010). OECD Economic Surveys : Spain, OECD Publishing, Paris.

[24] OECD (2012). OECD Economic Surveys : Spain, OECD Publishing, Paris.

[25] Onrubia Fernández, J., Romero Jordán, D. and J. F. Sanz Sanz (2004), "Compensación de incentivos a la adquisición de vivienda en la reforma del IRPF de 1999", Revista de Economía Aplicada 35 (vol. XII), 2004, pages 105-124

[26] Ortega, E., Rubio, M., Thomas, C., (2011), "House purchase versus rental in Spain", Moneda y Crédito 232, pages 109-144.

[27] Sanz, J. F., (2000), "Las ayudas fiscales a la adquisición de inmuebles residenciales en la nueva Ley del IRPF: un análisis comparado a través del concepto de coste de uso", Hacienda Pública Española 155, pages 49-176.

[28] Schmitt-Grohe, S., Uribe, M., (2001), Closing Small Open Economy Models, Departmental Working Papers 200115, Rutgers University, Department of Economics 


\section{Appendix}

Figure 1: Share of rented dwellings in Spain and other EU countries

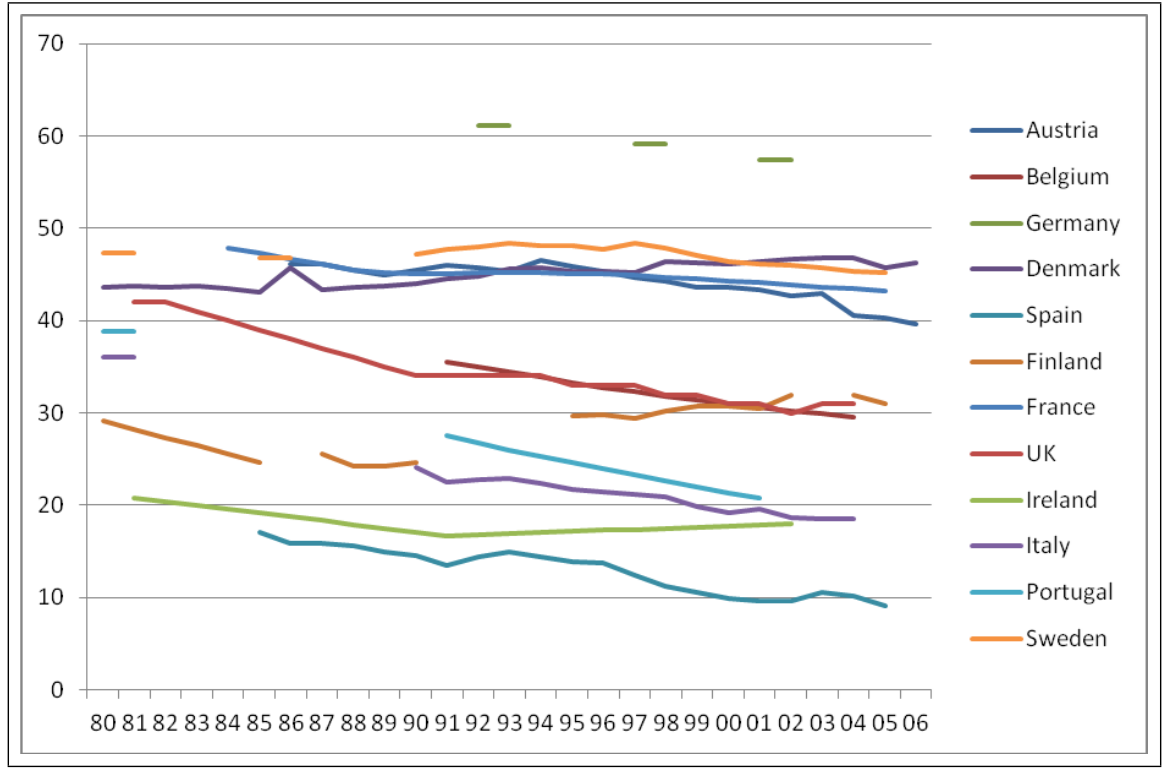

Source: Statistical Data Warehouse (2007) and the « Encuesta Continua de Presupuestos Familiares » for the case of Spain. 